\title{
Genetic potential of black bean genotypes with predictable behaviors in multienvironment trials
}

\author{
P.P. Torga ${ }^{1}$, P.G.S. Melo ${ }^{2}$, H.S. Pereira ${ }^{1}$, L.C. Faria ${ }^{1}$ and L.C. Melo ${ }^{1}$ \\ ${ }^{1}$ Embrapa Arroz e Feijão, Santo Antônio de Goiás, GO, Brasil \\ ${ }^{2}$ Escola de Agronomia, Universidade Federal de Goiás, Goiânia, GO, Brasil \\ Corresponding author: P.G.S. Melo \\ E-mail: pgsantos@gmail.com
}

Genet. Mol. Res. 15 (4): gmr15049029

Received July 25, 2016

Accepted August 30, 2016

Published October 24, 2016

DOI http://dx.doi.org/10.4238/gmr15049029

Copyright (C) 2016 The Authors. This is an open-access article distributed under the terms of the Creative Commons Attribution ShareAlike (CC BY-SA) 4.0 License.

\begin{abstract}
The aim of this study was to evaluate the phenotypic stability and specific and broad adaptability of common black bean genotypes for the Central and Center-South regions of Brazil by using the Annicchiarico and AMMI (weighted average of absolute scores: WAAS, and weighted average of absolute scores and productivity: WAASP) methodologies. We carried out 69 trials, with 43 and 26 trials in the Central and Center-South regions, respectively. Thirteen genotypes were evaluated in a randomized block design with three replications, during the rainy, dry, and winter seasons in 2 years. To obtain estimates of specific adaptation, we analyzed the parameters for each method obtained in the two geographic regions separately. To estimate broad adaptation, we used the average of the parameters obtained from each region. The lines identified with high specific adaptation in each region were not the same based on the Annicchiarico and AMMI (WAAS) methodologies. It was not possible to identify the same genotypes with
\end{abstract}


specific or broad stability by using these methods. By contrast, the Annicchiarico and AMMI (WAASP) methods presented very similar estimates of broad and specific adaptation. Based on these methods, the lines with more specific adaptation were CNFP 8000 and CNFP 7994, in the Central and Center-South regions, respectively, of which the CNFP 8000 line was more widely adapted.

Key words: AMMI; Annicchiarico; Phaseolus vulgaris; Genotype $\mathrm{x}$ environment interactions

\section{INTRODUCTION}

In recent years, Brazil has been ranked first in the production and consumption of common bean (Phaseolus vulgaris L.) (FAO, 2015). Black beans are the second most consumed type of bean in Brazil, representing $17 \%$ of the consumer market and corresponding to approximately 490,000 tons/year (Del Peloso and Melo, 2005). Together, the Central and Center-South regions of Brazil are responsible for $84 \%$ of Brazil's bean production (Pontes Junior et al., 2014).

The common bean is grown in the majority of the Brazilian states during more than one sowing period per year. This is done using different cultivation systems and under different environmental conditions, which leads to the occurrence of genotype $\mathrm{x}$ environment (GxE) interactions (Bertoldo et al., 2009; Pereira et al., 2009a, 2011; Domingues et al., 2013; Corrêa et al., 2016). Because of such interactions, the genotypes should be evaluated in a large number of environments so that the environmental effects can be measured and an improved certainty regarding the usage of new cultivars can be provided.

Adaptability and stability analyses can be used to minimize undesired effects of GxE interactions because they allow for the identification of cultivars that have predictable behaviors in response to variations in environmental conditions (Cruz and Regazzi, 2001). It is important to perform these analyses in different regions, to identify lineages that have both broad and specific adaptabilities and stabilities for each region. The obtained results can provide a level of certainty in decision-making processes. However, because of the low usage rate of common bean seeds by farmers (approximately 19\%) (Peske, 2016) and, consequently, the small market potential for new cultivars, common bean cultivars in Brazil are currently only indicated based on the average productivity of the different regions and planting seasons. In addition, cultivars are rarely recommended for specific environments.

Several methods are commonly used to evaluate the stability and phenotypic adaptability of cultivars, and several studies have compared different approaches. Silva and Duarte (2006) and Pereira et al. (2009b) found a low association between the Annicchiarico (Annicchiarico, 1992) and AMMI (additive main effects and multiplicative interaction model; Gauch and Zobel, 1996) methodologies, thereby demonstrating that these methods can be used to complement one another.

The methodology proposed by Annicchiarico (1992) has been widely used because of its ease of interpretation and because it classifies the most adaptable and stable genotypes with the greatest average productivity (Silva Filho et al., 2008; Pereira et al., 2009b,c, 2012). The AMMI method is also commonly used. It combines analysis of variance for the main additive effects of genotypes and environments with principal component analysis for the multiplicative

Genetics and Molecular Research 15 (4): gmr15049029 
effect of the GxE interaction (Gauch and Zobel, 1996). However, this methodology does not classify the most productive among the most stable genotypes (Melo et al., 2007; Silva Filho et al., 2008; Pereira et al., 2009b). This shortcoming becomes a problem when recommending new cultivars for the genetic improvement of plants, given that average productivity is one of the most relevant factors for the acceptance of new cultivars. With the goal of addressing this obstacle, it has been proposed that the AMMI methodology can make use of a supplementary genotype (Pacheco et al., 2005) that represents an additional reference genotype with which the evaluated genotypes can be compared. The reference genotype is defined based on the criteria of interest to the researcher. Another difficulty that generally occurs in the majority of studies that use the AMMI method is that the number of significant components defined by the decomposition of the GxE interaction is greater than the number of components used to study the stability (Melo et al., 2007; Rocha et al., 2007; Silva Filho et al., 2008; Pereira et al., 2009c; Gonçalves et al., 2010). To circumvent this problem, the use of a predictive evaluation via a cross-validation process has been proposed (Gauch, 1988). In this approach, the selected model is the one that displays the lowest average predictive difference among a large number of analyses (Oliveira et al., 2003). However, this method is difficult to use and, thus, impractical for implementation in routine plant breeding programs. In this regard, Pereira et al. (2009c) proposed calculation of the weighted average of the absolute scores (WAAS) of the first two principal components for each genotype, which are weighted by the percentage of variation explained by each component such that the genotypes with the lowest WAAS values are the most stable. Unfortunately, this method does not address all components identified as significant, nor does it include information about genotype productivity. Additionally, some of the aforementioned difficulties persist.

In the present study, a new approach to the AMMI methodology is proposed in which information on adaptability is included. Thus, this proposed method can be used in genetic improvement programs by including information from all significant components identified in the GxE interactions. The aim was to evaluate the phenotypic stability and specific and broad adaptability of common black bean genotypes in the Central and Center-South regions of Brazil by using the Annicchiarico and AMMI methods.

\section{MATERIAL AND METHODS}

Trials used to recommend black bean cultivars were conducted during the rainy (October/November sowing), dry (January/February sowing), and winter (May/June sowing) seasons in 43 environments of the Central region of Brazil (in the States of Goiás, the Federal District, Mato Grosso, Mato Grosso do Sul, and Tocantins) and 26 environments in the CenterSouth region (in the States of Paraná, Santa Catarina, São Paulo, and Rio Grande do Sul), totaling 69 environments in 2 years. The experimental design was a completely randomized block design with three repetitions and plots with four 4.0-m long rows. The data on bean productivity were collected from the two center rows. Each trial consisted of 13 genotypes of the common black bean as follows: eight elite lineages (TB 9409, TB 9713, CNFP 10138, CNFP 7966, CNFP 7972, CNFP 7994, CNFP 8000, and CNFP 9328) and five cultivars (BRS Valente, FT Nobre, Diamante Negro, IPR Uirapuru, and FT Soberano).

The data on bean yield $(\mathrm{kg} / \mathrm{ha})$ were subjected to an individual analysis of variance in which the effect of the genotypes was fixed and the other effects were random. Selective accuracy (SA) was estimated using the equation,

Genetics and Molecular Research 15 (4): gmr15049029 


$$
S A=\left[1-\left(\frac{1}{F}\right)\right]^{0.5}
$$

(Equation 1)

where $F$ is the value of the F-test for the source of variation of the lineages (Resende and Duarte, 2007). Subsequently, a joint analysis was performed on the stability and adaptability of the trials according to the region. For the trials in which the residual variances were not homogenous, the degrees of freedom of the mean error and of the GxE interaction were adjusted according to the Cochran method. The phenotypic means obtained in the joint analysis were subjected to a Scott and Knott means test at 10\% probability. The Annicchiarico and AMMI methodologies were used to estimate the adaptability and stability parameters associated with the bean yield of eight elite lineages.

In the Annicchiarico methodology, stability is measured by the superiority of the genotype relative to the mean for each environment. This method is based on the estimation of a recommendation index for a particular genotype that shows a relatively superior behavior. In this method, the data are transformed beforehand into percentages using the mean of the genotypes of each location as a reference. For example, if a cultivar obtains an index equal to $103.0 \%$, this cultivar will perform $3 \%$ better than the environmental average with a $75 \%$ probability.

The genotypic recommendation index $\left(w_{i(g)}\right)$ was estimated as follows:

$$
w_{i(g)}=\mu_{i(g)}-z_{(1-\alpha)} \delta_{z i(g)}
$$

(Equation 2)

where all environments are considered and $\mu_{i(g)}$ is the average percent of genotype i relative to the overall average, $z_{(1-\alpha)}$ is the percentile of the standard normal distribution, and $\delta_{z i(g)}$ is the standard deviation of the $z_{i j}$ values associated with genotype $\mathrm{i}$ :

$$
z_{i j}=\frac{100 Y_{i j}}{\bar{Y}_{. j}}
$$

where $Y_{i j}$ is the average of genotype $\mathrm{i}$ in environment $\mathrm{j}, \bar{Y}_{. j}$ is the average of environment $\mathrm{j}$. The index was also calculated using only the favorable environments (with a mean greater than the overall mean) or only the unfavorable ones (with a mean below the general mean). The adopted significance level was $75 \%$ or $\alpha=0.25$, which is commonly used in these analyses (Cruz and Carneiro, 2006). In this method, the performance of the genotype and its stability are simultaneously considered such that the greatest recommendation index values $\left(w_{i}\right)$ are obtained for those with the greatest average percentage $\left(z_{i}\right)$ and the least amount of deviation $\left(\delta_{z i}\right)$. Thus, $w_{i}$ is considered to express the genotypic stability and adaptability (Cruz and Carneiro, 2006). The AMMI analysis includes additive components to enable the study of the principal effects (genotypes and environments) and the interaction of multiplicative components. In the principal component analysis, the variation contained in the significant components is called the pattern, whereas that contained in the nonsignificant components is called noise. To use the AMMI methodology, the following model was employed:

Genetics and Molecular Research 15 (4): gmr15049029 


$$
Y_{i j}=\mu+g_{i}+a_{j}+\sum_{k-1}^{n} \lambda_{k} y_{i k} a_{j k}+\rho_{i j}+\bar{e}_{i j}
$$

where $Y_{i j}$ is the average response of genotype i in environment $\mathrm{j}, \mu$ is the general average of the trials, $g_{i}$ is the fixed effect of genotype $\mathrm{i}, a_{j}$ is the fixed effect of environment $\mathrm{j}, \lambda_{k}$ is the singular value (scalar) $\mathrm{k}$ of the matrix of original interactions (denoted GE), $Y_{i k}$ is the element corresponding to the $\mathrm{i}$-th genotype in the singular vector of column $\mathrm{k}$ in the GE matrix, $a_{j k}$ is the element corresponding to the $\mathrm{j}$-th environment in the $\mathrm{k}$-th singular vector of a line in the GE matrix, $\rho_{i j}$ is the noise associated with the term $(g e)_{i j}$ of the classic interaction of genotype $i$ with environment $\mathrm{j}$, and $\bar{e}_{i j}$ is the average experimental error. The Gollob F-test was used to select the model.

The method produces scores for the interaction principal component analysis (IPCA) for each genotype, which reflect their contribution to the GxE interaction. To identify the most stable genotypes, the means of the absolute scores were obtained following the method of Pereira et al. (2009b), obtained for each genotype for the principal components that were significant at $1 \%$ probability by the F-test weighted by the explanatory power of each component. Thus, the genotype with the lowest WAAS is the most stable. The expression used was

$$
W A A S_{i}=\frac{\sum_{i=1}^{n}\left(P E_{i} * I P C A_{i}\right)}{\sum_{i=1}^{n} P E_{i}}
$$

where $W A A S_{i}$ is the weighted average of the absolute scores for genotype i, $P E_{i}$ is the percentage of explanation of the $\mathrm{i}$-th significant principal component, and $I P C A_{i}$ is the estimate of the $\mathrm{i}$-th significant principal component.

With the goal of adding a new parameter to the AMMI methodology, by associating the stability with the adaptability, the use of the weighted mean of absolute scores and productivity (WAASP) was proposed. This value is the weighted mean of the average productivity of the genotypes, with a weight equal to 3 , and that of the WAAS, with a weight equal to 2 , that allows for the simultaneous evaluation of adaptability and stability. To obtain the WAASP, the productivity and WAAS data were transformed to the same scale to be directly comparable. The greatest productivity value was considered to be $100 \%$, and all other values were compared relative to this value. In the case of WAAS, all values were subtracted from 100 to invert the scale, and subsequently, the percentage relative to the greatest value for each genotype was obtained.

The expression used was

$$
W A A S P_{i}=\frac{\left\{3 *\left[\left(\frac{T F_{i}}{T F_{\text {greates }}}\right) * 100\right]\right\}+\left\{2 *\left[\left(\frac{100-W A A S_{i}}{W A A S_{\text {leat }}}\right) * 100\right]\right\}}{5}
$$

where $W A A S P_{i}$ is the weighted average of the absolute scores and the productivity for genotype i, $T F_{i}$ is the average productivity of genotype $\mathrm{i}, T F_{\text {greatest }}$ is the genotype with the greatest mean productivity, $W A A S_{i}$ is the weighted mean of the absolute scores of genotype $\mathrm{i}$, and $W A A S_{\text {leas }}$ is the genotype with the lowest WAAS value.

To obtain the estimates of the stability and adaptability specific to the regions, the parameters obtained with each method were analyzed separately for the two geographic regions. To estimate the broad stability and adaptability, the mean of the parameters obtained in each region was used, and a broad adaptation of the genotypes was considered for those with the highest estimates for this mean. Furthermore, estimates were obtained separately for the

Genetics and Molecular Research 15 (4): gmr15049029 
Spearman's correlation between the AMMI (WAAS) x Annicchiarico and AMMI (WAASP) $\mathrm{x}$ Annicchiarico methodologies for the two regions to determine the agreement of the genotype classifications. The estimation of the parameters and the significance tests were performed using Gene (Cruz, 2007) and SAS version 9.1 (SAS Institute, 2008).

\section{RESULTS AND DISCUSSION}

Significant genotype effects were found in $74 \%$ of the trials, and the values for the coefficient of variation were all less than $25 \%$, indicating good experimental precision (Tables 1 and 2). The magnitude of the SA estimates were high $(70 \leq \mathrm{SA}<90)$ or very high $(\mathrm{SA} \geq 90)$ in $65 \%$ of the cases and moderate $(50 \leq \mathrm{SA}<70)$ in $16 \%$ of the cases, thus confirming the good experimental precision (Tables 1 and 2). The use of the accuracy as a measure of experimental precision, as suggested by Resende and Duarte (2007), has the advantage of being independent of the magnitude of the mean. Thus, it better reflects what is desired in the experiment, i.e., an evaluation of the lineages or the uncertainty in using the phenotypic expression as an indicator of genotypic variation.

Table 1. Locations for the assessment trials in the Center-South region and a summary of the individual analyses of variance.

\begin{tabular}{|c|c|c|c|c|c|c|c|}
\hline \multirow{2}{*}{ Location } & \multirow{2}{*}{ Altitude (m) } & \multirow{2}{*}{ Season } & \multicolumn{2}{|c|}{ Mean squared } & \multirow{2}{*}{$\begin{array}{c}\text { Productivity } \\
(\mathrm{kg} / \mathrm{ha})\end{array}$} & \multirow{2}{*}{$\mathrm{CV}_{\mathrm{e}}(\%)$} & \multirow[t]{2}{*}{ SA } \\
\hline & & & Treatments & Error & & & \\
\hline Ponta Grossa-PR & 969 & Dry/2003 & $389,129^{\text {ns }}$ & 187,132 & 1949 & 22.2 & 0.72 \\
\hline Ponta Grossa-PR & 969 & Wet/2003 & $439,048^{*}$ & 175,261 & 3569 & 11.7 & 0.78 \\
\hline Taquarituba-SP & 618 & Wet/2004 & $751,390 * *$ & 117,376 & 2390 & 14.3 & 0.92 \\
\hline Itaberá-SP & 651 & Wet/2004 & $299,100^{*}$ & 112,587 & 2920 & 11.5 & 0.79 \\
\hline Paranapanema-SP & 610 & Wet/2004 & $467,368 * *$ & 96,048 & 2611 & 11.9 & 0.00 \\
\hline Abelardo Luz-SC & 760 & Wet/2003 & $387,347^{\mathrm{ns}}$ & 262,498 & 3916 & 13.1 & 0.57 \\
\hline C. Novos-SC & 934 & Wet/2003 & $64,346^{\mathrm{ns}}$ & 37,031 & 1056 & 18.2 & 0.65 \\
\hline Abelardo Luz-SC & 760 & Dry/2003 & $147,838^{*}$ & 62,043 & 2191 & 11.4 & 0.76 \\
\hline Major Vieira-SC & 786 & Wet $/ 2003$ & $293,351 * *$ & 68,292 & 1831 & 14.3 & 0.88 \\
\hline Concórdia-SC & 569 & Wet/2003 & $354,428 * *$ & 113,912 & 2255 & 14.9 & 0.82 \\
\hline Roncador-PR & 762 & Dry/2003 & $183,289^{* *}$ & 50,485 & 1383 & 16.3 & 0.85 \\
\hline Taquarituba-SP & 618 & Wet/2003 & $369,722 * *$ & 56,549 & 2217 & 10.7 & 0.92 \\
\hline Capão Bonito-SP & 705 & Wet/2003 & $366,642^{\text {ns }}$ & 284,165 & 4110 & 12.9 & 0.47 \\
\hline Londrina-PR & 585 & Wet/2003 & $640,498^{*}$ & 219,548 & 1938 & 24.2 & 0.81 \\
\hline Prudentópolis-PR & 840 & Dry/2004 & $220,195^{*}$ & 93,244 & 2554 & 11.9 & 0.76 \\
\hline Ponta Grossa-PR & 969 & Dry/2004 & $511,985 * *$ & 83,494 & 3163 & 9.1 & 0.00 \\
\hline Major Vieira-SC & 786 & Dry/2004 & $178,248 * *$ & 30,298 & 1663 & 10.5 & 0.91 \\
\hline Roncador-PR & 762 & Wet/2004 & $101,612 * *$ & 23,747 & 871 & 17.7 & 0.00 \\
\hline Prudentópolis-PR & 840 & Wet/2004 & $470,860 * *$ & 40,774 & 2246 & 8.9 & 0.96 \\
\hline Laranjeiras-PR & 840 & Wet/2004 & $129,640^{*}$ & 43,358 & 2538 & 8.2 & 0.82 \\
\hline C. Novos-SC & 934 & Wet/2004 & $80,000^{*}$ & 33,801 & 1367 & 13.5 & 0.76 \\
\hline Abelardo Luz-SC & 760 & Wet/2004 & $465,473 *$ & 158,017 & 3958 & 10.0 & 0.81 \\
\hline Ponta Grossa-PR & 969 & Wet/2004 & $630,750^{*}$ & 213,519 & 3320 & 13.9 & 0.81 \\
\hline Passo Fundo-RS & 687 & Wet/2003 & $250,151 * *$ & 48,213 & 1858 & 11.8 & 0.90 \\
\hline Passo Fundo-RS & 687 & Wet/2002 & $148,605^{*}$ & 52,866 & 3065 & 7.5 & 0.00 \\
\hline Abelardo Luz-SC & 760 & Dry/2004 & $115,335^{\mathrm{ns}}$ & 106,091 & 2184 & 14.9 & 0.28 \\
\hline Mean & - & - & - & - & 2428 & 13.3 & 0.65 \\
\hline
\end{tabular}

*and **Significant at 5 and $1 \%$ probability, respectively, according to the F-test. $\mathrm{CV}_{\mathrm{e}}$ : experimental coefficient of variation; SA: selective accuracy.

The average productivities of the Center-South region (Table 1) varied between 871 and $4110 \mathrm{~kg} / \mathrm{ha}$, demonstrating that the environmental conditions experienced by the genotypes were different. 
Table 2. Locations for the assessment trials in the Central region and a summary of the individual analyses of variance.

\begin{tabular}{|c|c|c|c|c|c|c|c|}
\hline \multirow[t]{2}{*}{ Location } & \multirow[t]{2}{*}{ Altitude (m) } & \multirow[t]{2}{*}{ Season } & \multicolumn{2}{|c|}{ Mean squared } & \multirow{2}{*}{$\begin{array}{c}\text { Productivity } \\
(\mathrm{kg} / \mathrm{ha})\end{array}$} & \multirow{2}{*}{$\begin{array}{l}\mathrm{CV}_{\mathrm{e}} \\
(\%)\end{array}$} & \multirow[t]{2}{*}{ SA } \\
\hline & & & Treatment & Error & & & \\
\hline Dueré-TO & 235 & Winter/2004 & $103,964^{\mathrm{ns}}$ & 114,872 & 1817 & 18.7 & 0.00 \\
\hline S. A. Goiás-GO & 770 & Dry/2003 & $169,991 *$ & 62,414 & 1277 & 19.6 & 0.80 \\
\hline Goiatuba-GO & 807 & Winter/2003 & $153,593^{\mathrm{ns}}$ & 113,986 & 1877 & 17.9 & 0.51 \\
\hline S. A. Goiás-GO & 770 & Winter/2003 & $387,691^{*}$ & 142,640 & 2019 & 18.7 & 0.00 \\
\hline Rio Verde-GO & 715 & Winter/2003 & $246,537^{\mathrm{ns}}$ & 167,317 & 2400 & 17.0 & 0.57 \\
\hline Urutaí-GO & 807 & Winter/2003 & $385,795^{\text {ns }}$ & 269,732 & 2677 & 19.4 & 0.55 \\
\hline Cristalina-GO & 1189 & Winter/2003 & $1416,966^{* *}$ & 252,109 & 2525 & 19.9 & 0.91 \\
\hline Rio Verde-GO & 807 & Wet/2003 & $890,179^{* *}$ & 82,075 & 2288 & 12.5 & 0.95 \\
\hline Ipameri-GO & 764 & Wet/2003 & $330,685^{* *}$ & 79,490 & 3044 & 9.3 & 0.87 \\
\hline Anápolis-GO & 1017 & Wet/2003 & $208,086^{\text {ns }}$ & 123,104 & 1870 & 18.8 & 0.64 \\
\hline Formosa-GO & 916 & Wet/2003 & $518,038^{* *}$ & 92,866 & 2299 & 13.3 & 0.91 \\
\hline Panamá-GO & 733 & Dry/2004 & $148,973^{*}$ & 58,817 & 1245 & 19.5 & 0.78 \\
\hline Anápolis-GO & 1017 & Dry/2004 & $236,833^{*}$ & 94,942 & 1560 & 19.8 & 0.77 \\
\hline S. A. Goiás-GO & 770 & Dry/2004 & $433,116^{* *}$ & 60,694 & 1969 & 12.5 & 0.93 \\
\hline Dueré-TO & 235 & Winter/2003 & $313,776^{* *}$ & 74,503 & 1755 & 15.6 & 0.87 \\
\hline Planaltina-DF & 944 & Winter/2003 & $389,305^{*}$ & 146,094 & 2482 & 15.4 & 0.79 \\
\hline Sinop-MT & 345 & Wet/2003 & $243,799 * *$ & 61,795 & 1321 & 18.8 & 0.86 \\
\hline Anápolis-GO & 1017 & Winter/2004 & $598,836^{\text {ns }}$ & 301,948 & 3082 & 17.8 & 0.70 \\
\hline S. A. Goiás-GO & 770 & Winter/2004 & $103,861^{\mathrm{ns}}$ & 71,688 & 2487 & 10.8 & 0.56 \\
\hline Rio Verde-GO & 807 & Winter/2004 & $218,253^{\text {ns }}$ & 115,424 & 2995 & 11.3 & 0.69 \\
\hline Itumbiara-GO & 448 & Winter/2004 & $256,492 *$ & 107,752 & 1961 & 16.7 & 0.76 \\
\hline Planaltina-DF & 944 & Wet/2003 & $152,205^{\text {ns }}$ & 190,776 & 2481 & 17.6 & 0.00 \\
\hline Urutaí-GO & 807 & Winter/2004 & $77,882 * *$ & 19,450 & 1672 & 8.3 & 0.87 \\
\hline Morrinhos-GO & 771 & Winter/2004 & $210,337^{* *}$ & 60,844 & 1944 & 12.7 & 0.00 \\
\hline Sinop-MT & 345 & Dry/2004 & 91,467* & 35,689 & 1153 & 16.4 & 0.78 \\
\hline Cáceres-MT & 118 & Winter/2004 & $280,151^{\text {ns }}$ & 151,610 & 2295 & 16.9 & 0.68 \\
\hline Dianópolis-TO & 693 & Winter/2003 & $309,476^{\text {ns }}$ & 210,484 & 3331 & 13.8 & 0.57 \\
\hline Palmas-TO & 230 & Winter/2003 & $166,305^{*}$ & 57,386 & 2177 & 11.0 & 0.00 \\
\hline Cáceres-MT & 118 & Winter/2003 & $53,470^{\text {ns }}$ & 255,509 & 2840 & 17.8 & 0.00 \\
\hline Morrinhos-GO & 771 & Wet/2004 & $244,289 * *$ & 53,762 & 2018 & 11.5 & 0.88 \\
\hline Urutaí-GO & 807 & Wet/2004 & $484,146^{* *}$ & 81,348 & 2040 & 13.9 & 0.91 \\
\hline Cristalina-GO & 1189 & Winter/2004 & $480,477 * *$ & 86,650 & 2951 & 9.9 & 0.00 \\
\hline C. Alegre-GO & 877 & Wet/2003 & $103,934^{\mathrm{ns}}$ & 68,173 & 1195 & 21.9 & 0.59 \\
\hline S. A. Goiás-GO & 770 & Wet/2004 & $173,477 * *$ & 19,065 & 1519 & 9.1 & 0.94 \\
\hline Anápolis-GO & 1017 & Wet/2004 & $256,431 * *$ & 38,172 & 2578 & 7.6 & 0.92 \\
\hline Rio Verde-GO & 807 & Wet/2004 & $684,442 * *$ & 191,497 & 2564 & 17.1 & 0.85 \\
\hline Cristalina-GO & 1189 & Wet/2004 & $428,605^{* *}$ & 96,722 & 1644 & 18.9 & 0.88 \\
\hline G. Dourados-MS & 400 & Dry/2003 & $140,838^{*}$ & 64,131 & 1695 & 14.9 & 0.74 \\
\hline Dourados-MS & 430 & Dry/2003 & $197,857^{* *}$ & 28,164 & 1808 & 9.3 & 0.93 \\
\hline Aquidauana-MS & 147 & Dry/2003 & $374,454 * *$ & 13,062 & 1719 & 6.6 & 0.98 \\
\hline Aquidauana-MS & 147 & Dry/2004 & $181,766^{* *}$ & 12,810 & 1719 & 6.6 & 0.96 \\
\hline Planaltina-DF & 944 & Winter/2004 & $370,446^{*}$ & 151,787 & 3422 & 11.4 & 0.77 \\
\hline Planaltina-DF & 944 & Wet/2004 & $544,875^{* *}$ & 130,046 & 3379 & 10.7 & 0.87 \\
\hline Mean & - & - & - & - & 2165 & 14.6 & 0.66 \\
\hline
\end{tabular}

*and **Significant at 5 and $1 \%$ probability, respectively, according to the $\mathrm{F}$-test. $\mathrm{CV}_{\mathrm{e}}$ : experimental coefficient of variation; SA: selective accuracy.

The same effect was observed in the Central Region (Table 2), in which the average productivities varied from 1153 to $3422 \mathrm{~kg} / \mathrm{ha}$. In the joint analysis of the two regions, all effects were significant. This indicates variability for the selection of genotypes, variation among the evaluated environments, and the occurrence of a differentiated response of the genotypes to the environments, which determines the need for an analysis of stability and adaptability (Table 3 ).

Genetics and Molecular Research 15 (4): gmr15049029 
Table 3. Summary of the joint analysis of variance with the use of the original GxE interaction via the AMMI model for 13 black common bean genotypes evaluated in the Central and Center-South regions of Brazil.

\begin{tabular}{|c|c|c|c|c|c|c|c|c|}
\hline \multirow[t]{2}{*}{ Source of variation } & \multicolumn{4}{|c|}{ Central } & \multicolumn{4}{|c|}{ Center-South } \\
\hline & $\%^{\dagger}$ & d.f. & SS & MS & $\%^{\dagger}$ & d.f. & SS & MS \\
\hline Genotype (G) & - & 12 & $23,734,170$ & $1,977,848^{* *}$ & - & 12 & $10,568,653$ & $880,721^{*}$ \\
\hline Environment (E) & - & 42 & $620,921,839$ & $14,783,853^{* *}$ & - & 25 & $749,435,646$ & $29,977,426^{* *}$ \\
\hline GxE & - & $353^{\ddagger}$ & $141,402,904$ & $400,575^{* *}$ & - & $205^{\ddagger}$ & $90,913,404$ & $443,480 * *$ \\
\hline IPCA 1 & 24 & 53 & $33,930,159$ & $640,192 * *$ & 23 & 36 & $21,066,863$ & $585,191 * *$ \\
\hline Residual 1 & - & 300 & $107,472,745$ & $358,242 * *$ & - & 169 & $69,846,542$ & $413,293 * *$ \\
\hline IPCA 2 & 18 & 51 & $25,874,470$ & $507,343^{* *}$ & 18 & 34 & $16,557,859$ & $486,996 * *$ \\
\hline Residual 2 & - & 249 & $81,598,275$ & $327,704 * *$ & - & 135 & $53,288,683$ & $394,731^{* *}$ \\
\hline IPCA 3 & 15 & 49 & $21,257,749$ & $433,832 * *$ & 15 & 32 & $13,701,942$ & $428,186^{* *}$ \\
\hline Residual 3 & - & 200 & $60,340,526$ & $301,703 * *$ & - & 103 & $39,586,741$ & $384,337 * *$ \\
\hline IPCA 4 & 9 & 47 & $12,514,278$ & $266,261 * *$ & 10 & 30 & $8,929,265$ & $297,642 * *$ \\
\hline Residual 4 & - & 153 & $47,826,249$ & $312,590 * *$ & - & 73 & $30,657,476$ & $419,965^{* *}$ \\
\hline IPCA 5 & 8 & 45 & $10,713,039$ & $238,068^{\text {ns }}$ & 9 & 28 & $7,854,755$ & $280,527^{* *}$ \\
\hline Residual 5 & - & 108 & $37,113,210$ & $343,641 * *$ & - & 45 & $22,802,721$ & $506,727^{* *}$ \\
\hline IPCA 6 & - & - & - & - & 8 & 26 & $6,994,674$ & $269,026^{\mathrm{ns}}$ \\
\hline Residual 6 & - & - & - & - & - & 19 & $15,808,047$ & $832,002 * *$ \\
\hline Error & - & $717^{\dagger}$ & - & 154,356 & - & $422^{\dagger}$ & - & 157,555 \\
\hline
\end{tabular}

†Proportion of explanation of the principal components. *Values adjusted by the Cochran method (1954) based on the heterogeneity of the residual MS values. $*$ and $* *$ Significant at 5 and $1 \%$ probability, respectively, according to the F-test.

The Annicchiarico method led to the identification of CNFP 8000, IPR Uirapuru, and FT Nobre as superior genotypes for the Central region of Brazil; these genotypes exceeded the mean of the environments by 5.3, 4.6, and 3.1\%, respectively. Considering the unfavorable environments, the genotypes that exceeded the mean were FT Nobre, CNFP 8000, IPR Uirapuru, and CNFP 7966, with respective values of 6.0, 5.9, 3.7, and $1.2 \%$. For the favorable environments, the best genotypes were CNFP 8000, CNFP 7994, and CNFP 10138, which showed 4.4, 3.0, and 0.9\% superiority relative to the mean, respectively (Table 4). Based on these results, the best genotype for all three environments in the Central region was CNFP 8000, which ranked first in the general analysis and in the favorable environments and second in the unfavorable environments. Genotypes CNFP 7966 and CNFP 7994 displayed adaptability specific to the unfavorable and favorable environments, respectively. All genotypes identified as being most stable and best adapted in this region were classified by the test of means into a group of the most productive genotypes (Table 4).

In the Center-South region, genotypes CNFP 7994, CNFP 8000, and TB 9713 were identified with a recommendation index $\left(w_{i}\right)$ greater than $100 \%$, and these genotypes exceeded the mean of the environments by 5.8, 2.0, and $1.2 \%$, respectively. In the unfavorable environments, in addition to the genotypes identified in the general analysis, the FT Nobre genotype was also identified as being superior by producing an index value $1.3 \%$ greater than the average. Considering the favorable environments, the notable genotypes were CNFP 7994, CNFP 10138, CNFP 8000, and IPR Uirapuru with $w_{i}$ values of 1.8, 1.7, 1.4, and 1.3\%, respectively (Table 4). In this region, it is worth highlighting the CNFP 7994 genotype, which ranked first in the three rounds of analysis (i.e., general, unfavorable, and favorable), which indicates that this genotype is the most adapted to the Center-South region of Brazil. This same genotype was the most productive along with CNFP 8000 according to the test of means (Table 4). When considering the two regions simultaneously, the best genotype was CNFP 8000 , which was superior to the mean for the environments in all rounds of analysis $\left(w_{\mathrm{i}}, w_{\mathrm{id}}\right.$, and $w_{\text {if }}>100$ ), with an average superiority relative to the two regions and the two types of

Genetics and Molecular Research 15 (4): gmr15049029 
environments of 3.6\%. This genotype was also recommended by Torga et al. (2013a,b), when they decomposed the GxE interaction in the genotypes $\mathrm{x}$ sowing season and genotypes $\mathrm{x}$ location/years, for these two regions, separately.

Table 4. Estimates of the parameters of adaptability and phenotypic stability of 13 genotypes of the black common bean, which were evaluated in the Central and Center-South regions of Brazil during 2003 and 2004 by the Annicchiarico (1992) method.

\begin{tabular}{|c|c|c|c|c|c|c|c|c|c|c|c|c|c|c|}
\hline \multirow[t]{2}{*}{ Genotype } & \multicolumn{7}{|c|}{ Central } & \multicolumn{7}{|c|}{ Center-South } \\
\hline & Mean & $w_{\mathrm{i}}$ & $\mathrm{C}$ & $w_{\text {id }}$ & $\mathrm{C}$ & $w_{\text {if }}$ & $\mathrm{C}$ & Mean & $w_{\mathrm{i}}$ & $\mathrm{C}$ & $w_{\text {id }}$ & $\mathrm{C}$ & $w_{\text {if }}$ & $\mathrm{C}$ \\
\hline CNFP 8000 & $2352^{\mathrm{a}}$ & 105.2 & 1 & 105.9 & 2 & 104.3 & 1 & $2592^{\mathrm{a}}$ & 102.0 & 2 & 102.9 & 3 & 101.3 & 4 \\
\hline FT Nobre & $2286^{\mathrm{a}}$ & 103.1 & 3 & 106.0 & 1 & 100.2 & 4 & $2441^{c}$ & 97.8 & 5 & 101.3 & 4 & 93.2 & 12 \\
\hline IPR Uirapuru & $2278^{\mathrm{a}}$ & 104.6 & 2 & 103.7 & 3 & 99.3 & 6 & $2444^{c}$ & 96.0 & 6 & 94.0 & 6 & 100.7 & 2 \\
\hline CNFP 7994 & $2261^{\mathrm{a}}$ & 100.1 & 4 & 97.6 & 7 & 103.0 & 2 & $2627^{\mathrm{a}}$ & 105.8 & 1 & 109.0 & 1 & 101.8 & 1 \\
\hline BRS Valente & $2232^{\mathrm{a}}$ & 99.6 & 5 & 99.3 & 5 & 99.8 & 5 & $2354^{\mathrm{d}}$ & 92.7 & 10 & 89.9 & 12 & 96.8 & 9 \\
\hline CNFP 10138 & $2227^{\mathrm{a}}$ & 98.4 & 7 & 96.2 & 8 & 100.9 & 3 & $2425^{\mathrm{c}}$ & 94.4 & 8 & 90.1 & 11 & 101.4 & 3 \\
\hline CNFP 7966 & $2226^{\mathrm{a}}$ & 99.3 & 6 & 101.2 & 4 & 97.1 & 7 & $2389^{c}$ & 95.7 & 7 & 93.9 & 7 & 98.4 & 8 \\
\hline CNFP 9328 & $2112^{\mathrm{b}}$ & 94.2 & 8 & 98.3 & 6 & 89.6 & 12 & $2495^{b}$ & 99.3 & 4 & 99.0 & 5 & 99.6 & 6 \\
\hline D. Negro & $2109^{\mathrm{b}}$ & 92.9 & 9 & 90.1 & 10 & 96.4 & 8 & $2324^{d}$ & 92.3 & 11 & 91.5 & 10 & 93.4 & 11 \\
\hline TB 9713 & $2082^{\mathrm{b}}$ & 91.9 & 10 & 90.7 & 9 & 93.3 & 9 & $2526^{\mathrm{b}}$ & 101.2 & 3 & 105.3 & 2 & 96.2 & 7 \\
\hline FT Soberano & $2047^{\mathrm{b}}$ & 91.3 & 11 & 90.0 & 11 & 92.8 & 10 & $2288^{\mathrm{d}}$ & 91.1 & 12 & 93.7 & 8 & 87.9 & 13 \\
\hline CNFP 7972 & $1983^{\mathrm{c}}$ & 88.0 & 12 & 88.8 & 12 & 87.0 & 13 & $2319^{d}$ & 90.2 & 13 & 84.3 & 13 & 99.6 & 5 \\
\hline TB 9409 & $1959^{\mathrm{c}}$ & 84.8 & 13 & 80.4 & 13 & 90.3 & 11 & $2338^{\mathrm{d}}$ & 93.4 & 9 & 92.9 & 9 & 94.4 & 10 \\
\hline
\end{tabular}

Means $(\mathrm{kg} / \mathrm{ha}$ ) followed by the same superscript letters do not differ significantly according to the Scott-Knott test at $10 \%$ probability. $\mathrm{C}=$ classification of the genotypes with regard to the stability and adaptability; $w_{\mathrm{i}}=$ recommendation index, classified into favorable environments $\left(w_{\mathrm{if})}\right.$ and unfavorable environments $\left(w_{\mathrm{id}}\right)$.

As previously mentioned, the most stable and adapted genotypes were also the most productive. This is expected given that the model used in the Annicchiarico method to measure genotype superiority uses the mean for each environment as a reference. Therefore, the risk of adopting a particular cultivar is estimated, and this estimate is obtained relative to the mean (Silva Filho et al., 2008; Pereira et al., 2009c, 2012).

According to the AMMI model, the original GxE interaction may be decomposed into 12 components (i.e., ranks within the GE matrix) for the Central and Center-South regions. In this type of analysis, the appropriate model associates significance with the axes and non-significance with the residuals. However, in this study, the analysis was problematic in that non-significance was found for the component (axis), and the residuals continued to be significant (Table 3). Thus, the selected model was the last one to display significance for the component. Oliveira et al. (2003) suggested that with regard to the level of significance, the use of $1 \%$ instead of $5 \%$ reduces the likelihood of a type I error; however, this approach increases the likelihood of the occurrence of a type II error. According to Gauch and Zobel (1996), the first AMMI components capture a greater percentage of the real performance "pattern", and with the subsequent accumulation of components, there is a decrease in the percentage of the "pattern" and an increase in imprecise information (i.e., "noise"), thus reducing the predictive power of the AMMI analysis. Therefore, the significance level adopted in the present study to classify the principal components as significant was 1\%, thereby selecting the AMMI 4 and AMMI 5 models for the Central and Center-South regions, respectively (Table 3).

For the common bean, methodologies that identify materials with broad adaptations are advantageous. This is mainly because of the seed production market, given that the rate of seed usage by farmers is low (close to 15\%), which makes it difficult to have a specific indication for each crop region. The identification of the most stable lineages using the AMMI method 
was performed using information from the significant principal components to obtain the mean of the absolute scores for each genotype weighted by the percent of explanation of each component (WAAS) (Tables 3 and 5) (Pereira et al., 2009c). A lower value of the weighted average indicates a more stable genotype, which is attributed to the lower contribution of the GxE interaction.

Table 5. Values of the significant principal components (IPCAs) for each genotype of the Central and CenterSouth regions of Brazil that were used to calculate the WAAS and for classification of the genotypes with regard to the stability using the AMMI (WAAS) and AMMI (WAASP) methods.

\begin{tabular}{|c|c|c|c|c|c|c|c|c|c|c|}
\hline \multirow[t]{2}{*}{ Genotypes } & \multicolumn{10}{|c|}{ Central } \\
\hline & Mean & IPCA1 & IPCA2 & IPCA3 & IPCA4 & IPCA5 & WAAS & $\mathrm{C}$ & WAASP & $\mathrm{C}$ \\
\hline CNFP 8000 & $2352^{\mathrm{a}}$ & -6.25 & 24.06 & -6.65 & -0.57 & - & 10.5 & 6 & 98.7 & 1 \\
\hline FT Nobre & $2286^{a}$ & 11.88 & -12.47 & 8.52 & 3.67 & - & 10.2 & 4 & 97.2 & 2 \\
\hline IPR Uirapuru & $2269^{a}$ & -4.20 & -3.17 & 32.92 & 3.11 & - & 10.3 & 5 & 96.7 & 3 \\
\hline CNFP 7994 & $2261^{\mathrm{a}}$ & -12.78 & 24.90 & -0.95 & 15.50 & - & 13.8 & 10 & 95.0 & 6 \\
\hline BRS Valente & $2232^{\mathrm{a}}$ & 1.62 & -9.14 & 8.67 & 28.97 & - & 9.0 & 3 & 96.4 & 4 \\
\hline CNFP 10138 & $2227^{\mathrm{a}}$ & -12.83 & 16.20 & 5.86 & -22.86 & - & 13.5 & 9 & 94.3 & 7 \\
\hline CNFP 7966 & $2226^{\mathrm{a}}$ & 20.03 & 12.96 & 1.59 & -0.65 & - & 11.3 & 7 & 95.2 & 5 \\
\hline CNFP 9328 & $2112^{\mathrm{b}}$ & 36.66 & -0.85 & -15.80 & -3.10 & - & 17.5 & 13 & 89.6 & 11 \\
\hline D. Negro & $2109^{b}$ & -0.36 & -18.48 & 17.45 & -18.00 & - & 11.6 & 8 & 92.1 & 8 \\
\hline TB 9713 & $2083^{b}$ & -14.43 & -23.72 & -19.94 & -3.04 & - & 16.7 & 12 & 89.2 & 12 \\
\hline FT Soberano & $2047^{\mathrm{b}}$ & -3.67 & -9.79 & -15.77 & 4.37 & - & 8.2 & 2 & 92.0 & 9 \\
\hline CNFP 7972 & $1983^{\mathrm{c}}$ & 11.45 & 5.14 & -4.65 & -7.39 & - & 7.6 & 1 & 90.6 & 10 \\
\hline \multirow[t]{2}{*}{ TB 9409} & $1959^{\mathrm{c}}$ & -27.15 & -5.65 & -11.26 & -0.02 & - & 14.0 & 11 & 87.2 & 13 \\
\hline & \multicolumn{10}{|c|}{ Center-South } \\
\hline CNFP 7994 & $2627^{\mathrm{a}}$ & -9.38 & -11.82 & 18.66 & -0.04 & -12.41 & 11.0 & 8 & 97.5 & 1 \\
\hline CNFP 8000 & $2592^{\mathrm{a}}$ & -17.09 & -17.34 & 12.12 & -11.85 & -10.22 & 14.7 & 11 & 95.1 & 4 \\
\hline TB 9713 & $2516^{\mathrm{b}}$ & 16.27 & 7.09 & -21.60 & -14.55 & -12.68 & 14.5 & 10 & 93.4 & 6 \\
\hline CNFP 9328 & $2496^{\mathrm{b}}$ & 2.01 & 15.10 & -11.78 & -3.23 & -14.43 & 8.7 & 5 & 95.4 & 2 \\
\hline IPR Uirapuru & $2444^{c}$ & 9.80 & 2.04 & 5.07 & 8.80 & 7.10 & 6.5 & 2 & 95.2 & 3 \\
\hline FT Nobre & $2441^{c}$ & -12.11 & 33.34 & 12.95 & -1.31 & 3.87 & 15.1 & 12 & 91.5 & 10 \\
\hline CNFP 10138 & $2425^{\mathrm{c}}$ & -19.07 & 1.14 & -8.66 & 4.77 & 1.67 & 8.7 & 4 & 93.8 & 5 \\
\hline CNFP 7966 & $2389^{c}$ & -7.17 & -13.83 & -11.89 & 10.85 & 1.89 & 9.6 & 6 & 92.6 & 9 \\
\hline BRS Valente & $2364^{\mathrm{d}}$ & 5.99 & 5.43 & 6.82 & 4.04 & 20.59 & 7.5 & 3 & 92.9 & 8 \\
\hline TB 9409 & $2338^{d}$ & 0.77 & 3.27 & 8.81 & -13.41 & 3.05 & 4.9 & 1 & 94.3 & 7 \\
\hline D. Negro & $2324^{\mathrm{d}}$ & 9.24 & -15.50 & -7.49 & -18.55 & 19.67 & 12.8 & 9 & 89.8 & 12 \\
\hline CNFP 7972 & $2319^{d}$ & -12.05 & -3.44 & -16.37 & 19.32 & 1.67 & 10.6 & 7 & 90.6 & 11 \\
\hline FT Soberano & $2288^{d}$ & 32.80 & -5.48 & 13.36 & 15.16 & -9.77 & 17.3 & 13 & 87.0 & 13 \\
\hline
\end{tabular}

Means followed by the same superscript letters do not differ significantly according to a Scott-Knott test at $10 \%$ probability. WAAS = weighted mean of the absolute scores. $\mathrm{C}=$ classification of the genotypes with regard to the stability. WAASP = weighted mean of absolute scores and productivity.

In the Central region, the first four components explained $66 \%$ of the variation (Table 3 ). The most stable genotypes in this region were CNFP 7972, FT Soberano, and BRS Valente with WAAS values of 7.6, 8.2, and 9.0, respectively (Table 5). The genotypes with the least amount of stability were CNFP 9328, TB 9713, and TB 9409 with values of 17.5, 16.7, and 14.0, respectively. In the Center-South region, five principal components were significant and explained $75 \%$ of the total variation (Table 3). The genotypes that showed the least contribution to the GxE interaction were TB 9409, IPR Uirapuru, and BRS Valente, which displayed the lowest WAAS values of 4.9, 6.5 , and 7.5, respectively. The most stable genotypes were FT Soberano, FT Nobre, and CNFP 8000 that displayed WAAS values of 17.3, 15.1, and 14.7, respectively (Table 5).

It can be observed that the genotypes classified as being among the most stable for the two regions, with the exception of BRS Valente in the Central region, were not the most productive (Table 5). For the Center-South region, the TB 9409 and BRS Valente genotypes, which ranked first and third in stability, respectively, were the least productive when classified 
according to the test of means (Table 5). The same result occurred for the Central region with the CNFP 7972 and FT Soberano genotypes, which were classified as the most stable genotypes but not the most productive. This may be considered a negative aspect of this methodology, given that to make recommendations for cultivars the factor of greatest relevance is the average productivity. This cannot be ignored in the final decision of selecting favorable lineages in a cultivar development program.

To circumvent the problem that the most stable genotypes were not among the most productive according to the AMMI methodology, the WAASP method was proposed to add information regarding the average productivity and stability. WAASP allowed for the identification of the CNFP 8000, FT Nobre, and IPR Uirapuru genotypes as the most adapted and stable for the Central region with values of 98.7, 97.2, and 96.7, respectively. In addition, the TB 9404, TB 9713, and CNFP 9328 genotypes were identified as being the least adapted and stable (Table 5). In the Center-South region, the WAASP method identified the CNFP 7994 (97.5), CNFP 9328 (95.4), and IPR Uirapuru (95.2) genotypes as the most stable, whereas the FT Soberano, Diamante Negro, and CNFP 7972 genotypes were among the least stable and adapted (Table 5). Based on the average WAASP values of the two regions, the genotypes with the broadest adaptation were CNFP 8000, CNFP 7994, and IPR Uirapuru. These genotypes may be recommended for the two regions without causing losses for the producers. CNFP 8000 was commercially launched as a cultivar with the name of BRS Esplendor in 13 Brazilian states (Costa et al., 2011).

In the Central region, the Spearman's correlation estimates for AMMI (WAAS) $\mathrm{x}$ Annicchiarico and AMMI (WAASP) x Annicchiarico were 0.13 and 0.92 , respectively. In the Center-South region, the corresponding estimates were 0.35 and 0.80 , respectively. It can be observed that with the use of the WAASP methodology, a greater similarity was obtained with the Annicchiarico results, indicating that it is possible to add information about average productivity of the beans to the AMMI methodology. Integration of bean productivity information into the AMMI method allows for identification of stable lineages with the best agronomic performance. This is a positive result because one of the cited advantages of the Annicchiarico method is the identification of the most stable genotypes among the most productive ones, which was also achieved by the WAASP methodology.

Because the stability and adaptability parameters of each methodology are different, the genotypes identified as being the most stable differed in some cases. Therefore, in the selection of the methods to be used, factors such as ease of analysis and interpretation of the results should be considered. In a study comparing the different methods for the analysis of stability and adaptability, Pereira et al. $(2009 \mathrm{~b}, 2012)$ recommended the use of the Annicchiarico methodology due its ease of use and because it identifies the most stable and adapted genotypes from among the most productive ones. Oliveira et al. (2003) suggested that, for the purposes of recommending cultivars, the most stable genotypes should also display a desirable performance, which is evaluated by the means. By taking these criteria into consideration when evaluating the stability of the suite of final tests with the goal of indicating which cultivars to use, the Annicchiarico and AMMI (WAASP) methodologies would be recommended for programs that develop cultivars. This is because these methods classify the most stable and adapted genotypes from among the most productive ones, whereas this is not the case with the AMMI (WAAS) analysis.

In conclusion, the lineage with the greatest specific adaptation for the Central region was CNFP 8000, whereas CNFP 7994 was identified for the Center-South region. In addition,

Genetics and Molecular Research 15 (4): gmr15049029 
the genotype with the broadest adaptation was CNFP 8000. The Annicchiarico and AMMI (WAAS) methodologies did not identify the same genotypes from among the most stable and adapted ones. The Annicchiarico and AMMI (WAASP) methodologies identified similar genotypes as being the most stable and adapted ones. The lineages with the greatest specific adaptation for the Central and Center-South regions of Brazil did not coincide when using the Annicchiarico and AMMI methodologies. The AMMI-WAASP methodology is efficient and easy to implement in plant-breeding programs.

\section{Conflicts of interest}

The authors declare no conflict of interest.

\section{ACKNOWLEDGMENTS}

The authors thank the Federal University of Goiás for the study opportunity and the Brazilian Coordination for the Improvement of Higher Education Personnel (CAPES) for the postgraduate scholarship of P.P. Torga. Embrapa Rice and Beans provided financial support for this research. P.G.S. Mello, H.S. Pereira, and L.C. Melo were supported by awards for technological development and innovative extension from the Brazilian Council for Scientific and Technological Development (CNPq).

\section{REFERENCES}

Annicchiarico P (1992). Cultivar adaptation and recommendation from alfalfa trials in Northern Italy. J. Genet. Breed. 46: $269-278$.

Bertoldo JG, Coimbra JLM, Nodari RO, Guidolin AF, et al. (2009). Stratification of the state of Santa Catarina in macroenvironments for bean cultivation. Crop Breed. Appl. Biotechnol. 9: 335-343. http://dx.doi.org/10.12702/1984-7033. v09n04a08

Corrêa AM, Teodoro PE, Gonçalves MC, Barroso LM, et al. (2016). Artificial intelligence in the selection of common bean genotypes with high phenotypic stability. Genet. Mol. Res. 15: 10.4238/gmr.15028230.

Costa JGC, Melo LC, Pereira HS, Del Peloso MJ, et al. (2011). BRS Esplendor - cultivar de feijoeiro com grãos pretos, arquitetura ereta e resistência a doenças. Crop Breed. Appl. Biotechnol. 11: 276-279. http://dx.doi.org/10.1590/ $\underline{\text { S1984-70332011000300011 }}$

Cruz CD (2007). Programa Genes: aplicativo computacional em genética e estatística. Editora UFV, Viçosa.

Cruz CD and Regazzi AJ (2001). Modelos biométricos aplicados ao melhoramento genético. Editora UFV, Viçosa.

Cruz CD and Carneiro PCS (2006). Modelos biométricos aplicados ao melhoramento genético. Editora UFV, Viçosa.

Del Peloso MJ and Melo LC (2005). Potencial de rendimento da cultura do feijoeiro-comum. Editora Embrapa Arroz e Feijão, Santo Antônio de Goiás.

Domingues LS, Ribeiro ND, Minetto C, Souza JF, et al. (2013). Metodologias de análise de adaptabilidade e de estabilidade para a identificação de linhagens de feijão promissoras para o cultivo no Rio Grande do Sul. Semin. Cienc. Agrar. 34: 1065-1076. http://dx.doi.org/10.5433/1679-0359.2013v34n3p1065

FAO (2015). Food and agriculture organization of the United Nations. FAOSTAT. Available at [http://faostat3.fao.org/ browse/Q/QC/E]. Accessed January 6, 2015.

Gauch HG (1988). Model selection and validation for yield trails with interaction. Biometrics 44: 705-715. http://dx.doi. org $10.2307 / 2531585$

Gauch HG and Zobel RW (1996). AMMI analysis of yield trials. In: Genotype by environment interaction (Kang MS and Gauch HG, eds.). CRC Press, Boca Raton, 85-122.

Gonçalves JGR, Chiorato AF, Morais LK, Perina EF, et al. (2010). Estudo da estabilidade fenotípica de feijoeiro com grãos especiais. Cienc. Agrotec. 34: 922-931. http://dx.doi.org/10.1590/S1413-70542010000400018

Melo LC, Melo PGS, Faria LC, Diaz JLC, et al. (2007). Interação com ambientes e estabilidade de genótipos de feijoeirocomum na Região Centro-Sul do Brasil. Pesqui. Agropecu. Bras. 42: 715-723. http://dx.doi.org/10.1590/S0100$\underline{204 X 2007000500015}$

Genetics and Molecular Research 15 (4): gmr15049029 
Oliveira AB, Duarte JB and Pinheiro JB (2003). Emprego da análise AMMI na avaliação da estabilidade produtiva em soja. Pesqui. Agropecu. Bras. 38: 357-364. http://dx.doi.org/10.1590/S0100-204X2003000300004

Pacheco RM, Duarte JB, Vencovsky R, Pinheiro JB, et al. (2005). Use of supplementary genotypes in AMMI analysis. Theor. Appl. Genet. 110: 812-818. http://dx.doi.org/10.1007/s00122-004-1822-6

Pereira HS, Melo LC, Faria LC, Díaz JLC, et al. (2009a). Stability and adaptability of carioca common bean genotypes in states of the Central South Region of Brazil. Crop Breed. Appl. Biotechnol. 9: 181-188. http://dx.doi. org/10.12702/1984-7033.v09n02a11

Pereira HS, Melo LC, Del Peloso MJ, Faria LC, et al. (2009b). Comparação de métodos de análise de adaptabilidade e estabilidade fenotípica em feijoeiro-comum. Pesqui. Agropecu. Bras. 44: 374-383. http://dx.doi.org/10.1590/S0100204X2009000400007

Pereira HS, Melo LC, Faria LC, Del Peloso MJ, et al. (2009c). Adaptabilidade e estabilidade de genótipos de feijoeirocomum com grãos tipo carioca na Região Central do Brasil. Pesqui. Agropecu. Bras. 44: 29-37. http://dx.doi. org/10.1590/S0100-204X2009000100005

Pereira HS, Melo LC, Del Peloso MJ, Faria LC, et al. (2011). Complex interaction between genotypes and growing seasons of carioca common bean in Goiás/Distrito Federal. Crop Breed. Appl. Biotechnol. 11: 207-215.

Pereira HS, Almeida VM, Melo LC, Wendland A, et al. (2012). Influência do ambiente em cultivares de feijoeiro-comum em cerrado com baixa altitude. Bragantia 71: 165-172. http://dx.doi.org/10.1590/S0006-87052012005000024

Peske ST (2016). O mercado de sementes do Brasil. Seed News 20: 30-37.

Pontes Junior VA, Melo PGS, Pereira HS, Faria LC, et al. (2014). Characterization of final trials for cultivar release of Brazilian common bean assay network coordinated by Embrapa. Annu. Rep. Bean Improv. Coop. 57: 305-306.

Resende MDV and Duarte JB (2007). Precisão e controle de qualidade em experimentos de avaliação de cultivares. Pesqui. Agropecu. Trop. 37: 182-194.

Rocha MM, Freire Filho FR, Ribeiro VQ, Carvalho HWL, et al. (2007). Adaptabilidade e estabilidade produtiva de genótipos de feijão-caupi de porte semi-ereto na Região Nordeste do Brasil. Pesqui. Agropecu. Bras. 42: 1283-1289. http://dx.doi.org/10.1590/S0100-204X2007000900010

SAS Institute (2008). SAS/STAT: user's guide, version 9.2. SAS Institute, Cary.

Silva WCJ and Duarte JB (2006). Métodos estatísticos para estudo de adaptabilidade e estabilidade fenotípica em soja. Pesqui. Agropecu. Bras. 41: 23-30. http://dx.doi.org/10.1590/S0100-204X2006000100004

Silva Filho JL, Morello CL, Farias FJC, Lamas FM, et al. (2008). Comparação de métodos para avaliar a adaptabilidade e estabilidade produtiva em algodoeiro. Pesqui. Agropecu. Bras. 43: 349-355. http://dx.doi.org/10.1590/S0100$\underline{204 X 2008000300009}$

Torga PP, Melo PGS, Pereira HS, Faria LC, et al. (2013a). Interaction of common beans cultivars of the black group with years, locations and sowing seasons. Euphytica 189: 239-248. http://dx.doi.org/10.1007/s10681-012-0793-y

Torga PP, Melo PGS, Pereira HS, Faria LC, et al. (2013b). Decomposition of the interaction of common black bean group genotypes with the environment. Agric. Sci. 4: 683-688.

Genetics and Molecular Research 15 (4): gmr15049029 